\title{
PENGARUH UDARA LEBIH DAN UDARA SEKUNDER TERHADAP KARAKTERISTIK PEMBAKARAN PADA CIRCULATING FLUIDIZED BED COMBUSTOR
}

\author{
Sayid Ibrahim \\ Departemen Teknik Mesin dan Industri, Fakultas Teknik, \\ Universitas Gadjah Mada \\ Email: sayid127@gmail.com \\ Tri Agung Rohmat \\ Departemen Teknik Mesin dan Industri, Fakultas Teknik, \\ Universitas Gadjah Mada \\ Email: triagung_rohmat@ugm.ac.id
}

\begin{abstract}
ABSTRAK
Circulating Fluidized Bed Combustor (CFBC) merupakan reaktor pembakaran yang melibatkan partikel pasir terfluidisasi yang mengalir bersama udara. Pasir adalah media dengan kapasitas kalor yang besar sehingga dapat mendistribusikan kalor lebih baik dibandingkan gas. Tujuan dalam penelitian ini adalah untuk mengetahui pengaruh penambahan udara lebih (excess air) dan penggunaan udara sekunder terhadap karakteristik CFBC berupa komposisi flue gas yang dihasilkan dari reaksi pembakaran dan distribusi temperatur. Dalam penelitian ini, dilakukan simulasi numerik berbasis multiphase particle-in-cell (MP-PIC). Model CFBC terdiri dari bagian pokok: riser tempat terjadinya proses pembakaran dengan tinggi $3 \mathrm{~m}$, siklon alat untuk memisahkan partikel pasir dari aliran flue gas, dan loop-seal yang merupakan non-mechanical valve untuk memisahkan riser dan siklon. Udara primer (PA) dialirkan dari bagian bawah riser, batubara dimasukkan ke riser pada ketinggian $35 \mathrm{~cm}$ dari dasar riser, dan udara sekunder (SA) diinjeksikan di atas saluran batubara. Digunakan 3 variasi berdasar udara lebih (EA) dan ada tidaknya SA yaitu Variasi 1 (stoikiometris, hanya PA), Variasi 2 (EA=24\%, hanya PA), dan Variasi 3 (EA=46\%, PA dan SA). Hasil menunjukkan bahwa pada Variasi 1 pembakaran terjadi dengan baik walaupun intermediate spesies $\mathrm{CO}, \mathrm{CH}_{4}$, dan $\mathrm{H}_{2}$ terbentuk dalam jumlah cukup banyak. Dengan menambahkan jumlah udara (Variasi 2) maka intermediate spesies turun drastis. Penambahan jumlah udara melalui SA (Variasi 3) menurunkan pembentukan intermediate spesies lebih jauh sampai 50\% dibandingkan Variasi 2. Penambahan udara lebih juga berakibat penurunan temperatur di dalam riser secara keseluruhan.
\end{abstract}

Kata Kunci: circulating fluidized bed combustor, MP-PIC, udara lebih, udara primer, udara sekunder

\section{ABSTRACT}

Circulating Fluidized Bed Combustor (CFBC) is a combustion reactor that involves fluidized sand particles flowing with the air. Sand is a medium with large heat capacity so that it can distribute heat better than gas. The purpose of this study was to determine the effects of adding excess air and use of secondary air on the flue gas composition and temperature distribution. In this research, a multiphase particle-in-cell (MP-PIC) based numerical simulation was carried out. The CFBC model consists of the main parts: a riser where the combustion process occurs with a height of $3 \mathrm{~m}$, a cyclone device for separating sand particles from the flue gas, and a loop-seal, which is a non-mechanical valve, for separating the riser and the cyclone. Primary air (PA) is flowed from the bottom of the riser, coal is fed into the riser at a height of $35 \mathrm{~cm}$ from the bottom 
of the riser, and secondary air (SA) is injected over the coal input. Three variations based on the excess air (EA) and the presence of SA were used, namely Variation 1 (stoichiometric, PA only), Variation $2(E A=24 \%, P A$ only), and Variation $3(E A=46 \%, P A$ and $S A)$. The results showed that in Variation 1 the combustion occurred well even though the intermediate species $\mathrm{CO}, \mathrm{CH}_{4}$, dan $\mathrm{H}_{2}$ were formed in large numbers. By increasing the amount of air (Variation 2), the intermediate species dropped drastically. Increasing the amount of air through SA (Variation 3) reduced the formation of intermediate species even further by 50\% compared to Variation 2. The addition of more air also resulted in temperature decrease along the riser.

Keywords: circulating fluidized bed combustor, MP-PIC, excess air, primary air, secondary air

\section{PENDAHULUAN}

Batubara adalah sumber energi utama pembangkit listrik tenaga uap di Indonesia yang mencapai 45\% di tahun 2018 [1]. Indonesia memiliki berbagai macam jenis batubara termasuk batubara kualitas rendah. Di sisi lain, teknologi circulating fluidized bed (CFB) telah berkembang dalam beberapa dekade terakhir karena fleksibilitas bahan bakar, kontrol pembentukan $\mathrm{NO}_{\mathrm{x}}$ yang efektif, dan efisiensi penangkapan sulfur yang tinggi. Hasilnya, teknologi CFB dianggap sebagai pilihan terbaik untuk memanfaatkan batubara kualitas rendah [2].

Pada tahun 2019 pemerintah melalui Menteri Lingkungan Hidup dan Kehutanan mengeluarkan Peraturan Menteri P.15/MENLHK/SETJEN/KUM.1/4/2019 tentang Baku Mutu Emisi Pembangkit Listrik Tenaga Termal. Dalam peraturan menteri tersebut ditetapkan baku mutu emisi $\mathrm{SO}_{2}$ dan $\mathrm{NO}_{\mathrm{x}}$ harus kurang dari $200 \mathrm{mg} / \mathrm{Nm}^{3}$. Untuk memenuhi baku mutu ini, PLTU baru yang menggunakan teknologi CFB di Indonesia adalah keniscayaan.

Salah satu cara untuk menurunkan emisi dalam CFB adalah dengan menggunakan injeksi udara sekunder (SA). Udara sekunder diperoleh dengan membagi udara yang dibutuhkan untuk fluidisasi menjadi aliran udara primer dan sekunder. Udara primer (PA) diinjeksikan dari plat distributor udara di bagian bawah riser dan udara sekunder (SA) dialirkan ke dalam riser pada suatu ketinggian tertentu. Brereton dalam [3] menyebutkan bahwa injeksi SA tidak hanya cara yang efektif untuk mengontrol pembentukan thermal NO, tetapi juga dapat digunakan untuk pengendalian beban pada boiler CFB.

Di sisi lain, penambahan SA memberikan pengaruh terhadap hidrodinamika di dalam riser. Hal ini dapat meningkatkan kinerja dan memunculkan desain baru CFB. Beberapa studi fokus pada efek injeksi SA secara aksial [4][5]. Berdasarkan studi ini, diketahui bahwa injeksi SA mengubah distribusi partikel secara aksial, distribusi kecepatan partikel arah radial dan fluks massa partikel secara signifikan, terutama di sekitar wilayah injeksi SA. Desain perangkat injeksi SA, ketinggian port injeksi SA dari plat distributor dan rasio aliran volumetrik udara sekunder ke primer (SA/PA) adalah parameter utama yang mempengaruhi aliran gas-padat dalam unit CFB dengan udara sekunder.

Rao dan Reddy menginjeksikan udara lebih (EA) sebagai SA ke dalam freeboard ruang bakar CFB yang menggunakan bahan bakar serbuk gergaji kayu. Hasilnya menunjukkan peningkatan temperatur suhu di seluruh bagian ruang bakar. Kadar CO teramati menurun secara drastis, bahkan pada EA yang rendah. Hal ini karena injeksi SA membuat daerah freeboard menjadi lebih lebar dan menciptakan pencampuran yang intensif antara udara pembakaran dengan volatile matter dari sebuk gergaji sehingga menurunkan konsentrasi CO. Selain itu, arang karbon yang tersisa juga berkurang secara signifikan hampir 40\% [6].

Kobro dan Brereton menginjeksikan SA dalam pembakaran bertingkat dengan menempatkan lubang SA di bagian atas riser untuk mengontrol proses pembakaran. Hasilnya menunjukkan injeksi SA mempengaruhi stoikiometri reaksi pembakaran dan karakteristik fluidisasi di dalam riser [7]. Di sisi lain, injeksi SA juga mempengaruhi perpindahan panas pada dinding riser karena perpindahan kalor sebanding dengan kepadatan rata-rata pasir pada penampang riser. Dengan 
demikian, jumlah dan jenis injeksi SA harus ditentukan untuk memberikan informasi awal untuk perancangan CFBC [8].

Untuk mengevaluasi pengaruh rasio aliran udara primer dan udara total (PAT) terhadap kinerja boiler CFB, Lee dkk [9] memvariasikan rasio PAT dari 0,46 menjadi 0,86. Ketika rasio PAT meningkat, fraksi partikel dan suhu di dalam freeboard meningkat. Akibatnya, laju sirkulasi partikel dan penyerapan panas di dalam tungku meningkat seiring dengan peningkatan rasio PAT. Di sisi lain, emisi $\mathrm{SO}_{2}$ menurun karena peningkatan limestone di dapur, dan efisiensi pembakaran sedikit meningkat seiring dengan peningkatan rasio PAT. Oleh karena itu, perubahan rasio PAT dari boiler CFB dapat mengontrol kinerja boiler seperti temperatur dapur, temperatur uap, emisi gas dan efisiensi pembakaran.

Adapun tujuan penelitian ini adalah untuk mengetahui pengaruh penambahan udara lebih dan penggunaan udara sekunder terhadap karakteristik CFBC berupa komposisi flue gas yang dihasilkan dari reaksi pembakaran dan distribusi temperatur.

\section{METODOLOGI}

Reaktor CFB combustor yang akan disimulasikan dalam penelitian dibuat berdasarkan parameter-parameter desain [10] dan dapat dilihat pada Gambar 1 (a) . Model CFB terdiri dari riser (tinggi $3000 \mathrm{~mm}$ dan diameter $100 \mathrm{~mm}$ ) yaitu reaktor dimana terjadi proses pembakaran, dan siklon (tipe tangential entry, tipe Stairmand high efficiency, diameter $200 \mathrm{~mm}$ ) dimana terjadi pemisahan partikel padat dari gas hasil pembakaran. Antara siklon dan riser terdapat stand-pipe (diameter $75 \mathrm{~mm}$ ) dan katup non-mekanik berupa U-type loop-seal (panjang 187,5 mm, lebar 93,75 mm). Penggunaan katup non-mekanik bertujuan untuk mencegah terjadinya aliran gas dari riser ke siklon yang dapat menyebabkan terhambatnya aliran partikel kembali ke riser.

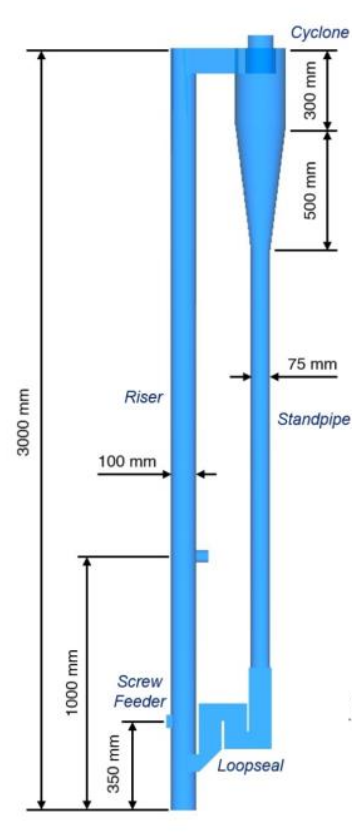

(a)

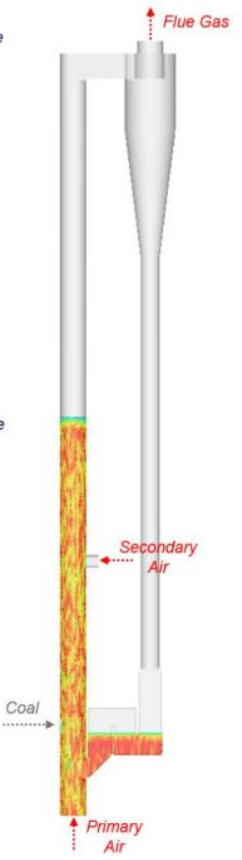

(b)

\section{Gambar 1. Model CFBC}


Gambar 1 (b) menunjukkan kondisi awal pasir, posisi udara dan batubara dialirkan masuk ke dalam reaktor. Pasir silika dengan massa $20 \mathrm{~kg}$ diletakkan di riser dan loop-seal masing-masing dengan fraksi volume 0,55 . Udara primer dialirkan dari distributor udara yang diletakkan di bagian bawah riser dengan kecepatan tertentu dan akan bereaksi dengan batubara yang masuk dengan laju massa tertentu. Selain berfungsi sebagai oksidator, udara primer juga mendorong pasir terfluidisasi sehingga tercapai rezim fast fluidization. Udara sekunder diinjeksikan pada posisi ketinggian 1000 $\mathrm{mm}$ di atas distributor udara primer. Ketika terjadi reaksi pembakaran antara udara dan batubara, pasir menyerap kalor dari proses pembakaran.

Model CFB seperti di atas kemudian dilakukan griding. Dalam penelitian ini grid yang digunakan adalah sebesar 289800. Hasil akhir griding dapat dilihat pada Gambar 2.

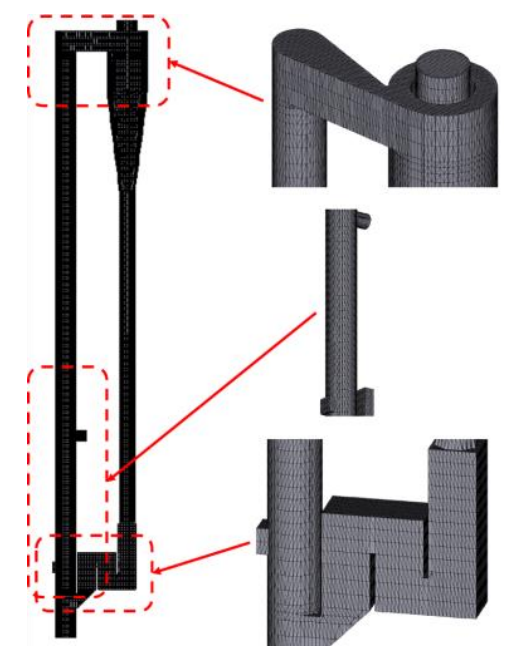

\section{Gambar 2. Griding Domain Komputasi}

Untuk mengetahui pengaruh jumlah udara dan keberadaan SA maka dilakukan simulasi dengan 3 variasi seperti dapat dilihat pada Tabel 1. Variasi 1 dan 2 hanya menggunakan PA dengan perbedaan jumlah udara lebih. Adapun Variasi 3 menggunakan PA dan SA, dan udara lebih yang paling besar,

Properti pada boundary condition dari masing-masing variasi dapat dilihat pada Tabel 2. Di tabel ini dapat dilihat kondisi untuk temperatur dan flow rate tidak konstan tetapi berubah terhadap waktu. Angka yang di depan menunjukkan nilai awal dan angka di dalam kurung adalah nilai akhir. Nilai awal dijalankan selama 3 detik, kemudian diubah secara gradual, sampai nilai akhir dimana nilai akhir dijalankan selama 30 detik untuk mendapatkan hasil yang steady. Temperatur tinggi di awal simulasi dibutuhkan untuk menginisiasi pembakaran. Terkait dengan hal ini, kecepatan dan flow rate juga ikut mengalami penyesuaian.

Tabel 1 Kondisi Udara Lebih Pada Berbagai Variasi

\begin{tabular}{|c|c|c|c|}
\hline \multirow{2}{*}{ Variasi } & \multirow{2}{*}{$\begin{array}{l}\text { Udara } \\
\text { Lebih }\end{array}$} & \multicolumn{2}{|c|}{ \% Udara Masuk } \\
\hline & & Primer & Sekunder \\
\hline Variasi 1 & 0 & $100 \%$ & $0 \%$ \\
\hline Variasi 2 & 24,24 & $100 \%$ & $0 \%$ \\
\hline Variasi 3 & 46,32 & $75,9 \%$ & $24,1 \%$ \\
\hline
\end{tabular}


Tabel 2 Properti Boundary Condition Untuk Simulasi Thermal Flow

\begin{tabular}{|c|c|c|c|}
\hline \multicolumn{4}{|c|}{ Cold Stream Boundary Condition } \\
\hline & Variasi 1 & Variasi 2 & Variasi 3 \\
\hline \multicolumn{4}{|l|}{ Primary Air Inlet } \\
\hline Temperature, $\mathrm{K}$ & \multicolumn{3}{|c|}{300 (1020) } \\
\hline Pressure, $\mathrm{Pa}$ & \multicolumn{3}{|c|}{101325} \\
\hline Velocity, $\mathrm{m} \mathrm{s}^{-1}$ & $2,1(4,9)$ & $3,3(6,2)$ & $2,1(4,9)$ \\
\hline Mass Flow Rate, $\mathrm{kg} \mathrm{s}^{-1}$ & $0,0235(0,01359)$ & $0,029(0,0179)$ & $0,0235(0,01359)$ \\
\hline \multicolumn{4}{|l|}{ Secondary Air Inlet } \\
\hline Temperature, $\mathrm{K}$ & \multicolumn{3}{|c|}{$1020(300)$} \\
\hline Pressure, $\mathrm{Pa}$ & \multicolumn{3}{|c|}{101325} \\
\hline Mass Flow Rate, $\mathrm{kg} \mathrm{s}^{-1}$ & 0 & 0 & $0,0112(0,0065)$ \\
\hline \multicolumn{4}{|l|}{ Loopseal Aeration } \\
\hline Temperature, $\mathrm{K}$ & \multicolumn{3}{|c|}{$300(1020)$} \\
\hline Pressure, $\mathrm{Pa}$ & \multicolumn{3}{|c|}{101325} \\
\hline Mass Flow Rate, $\mathrm{kg} \mathrm{s}^{-1}$ & \multicolumn{3}{|c|}{0,000521} \\
\hline \multicolumn{4}{|l|}{ Fuel Inlet } \\
\hline Gas & \multicolumn{3}{|c|}{ Air } \\
\hline Temperature, $\mathrm{K}$ & \multicolumn{3}{|c|}{300 (1020) } \\
\hline Pressure, $\mathrm{Pa}$ & \multicolumn{3}{|c|}{101325} \\
\hline Gas Mass Flow Rate, $\mathrm{kg} \mathrm{s}^{-1}$ & \multicolumn{3}{|c|}{0.000214} \\
\hline Coal Mass Flow Rate, $\mathrm{kg} \mathrm{s}^{-1}$ & 0,00325 & 0,00325 & 0,00325 \\
\hline \multicolumn{4}{|l|}{ Outlet } \\
\hline Pressure, $\mathrm{Pa}$ & Ambient & Ambient & Ambient \\
\hline
\end{tabular}

Tabel 3 Reaksi Kimia Yang Digunakan

\begin{tabular}{clc}
\hline \hline & & Reaksi Homogen \\
\hline \hline No & Nama Reaksi & Persamaan Reaksi \\
\hline R-1 & Oksidasi CH & \\
R-2 & Oksidasi $\mathrm{H}_{2}$ & $\mathrm{CH}_{4}+\mathrm{O}_{2} \rightarrow \mathrm{CO}_{2}+2 \mathrm{H}_{2} \mathrm{O}$ \\
R-3 & Oksidasi CO & $\mathrm{H}_{2}+0,5 \mathrm{O}_{2} \rightarrow \mathrm{H}_{2} \mathrm{O}$ \\
R-4 & Water Gas-Shift Reaction (Forward) & $\mathrm{CO}+0,5 \mathrm{O}_{2} \rightarrow \mathrm{CO}_{2}$ \\
R-5 & Water Gas-Shift Reaction (Reverse) & $\mathrm{CO}+\mathrm{H}_{2} \mathrm{O} \rightarrow \mathrm{CO}_{2}+\mathrm{H}_{2}$ \\
\hline \hline & \multicolumn{2}{c}{ Reaksi Heterogen } \\
\hline \hline No & Nama Reaksi & $\mathrm{CO}_{2}+\mathrm{H}_{2} \rightarrow \mathrm{CO}+\mathrm{H}_{2} \mathrm{O}$ \\
\hline R-6 & Oksidasi C(s) & Persamaan Reaksi \\
R-7 & Gasifikasi C(s) & $\mathrm{C}+0,53 \mathrm{O}_{2} \rightarrow 0,93 \mathrm{CO}+0,07 \mathrm{CO}_{2}$ \\
\hline \hline
\end{tabular}

Tabel 4 Kinetika Reaksi

\begin{tabular}{clll}
\hline \hline & & \multicolumn{1}{c}{ Kinetika dan Laju Reaksi } & \multicolumn{1}{c}{ Sumber } \\
\hline \hline $\mathrm{No}$ & \multicolumn{1}{c}{ Laju Reaksi } & \multicolumn{1}{c}{ Konstanta Laju Reaksi } & Yan, et al. [11] \\
\hline $\mathrm{R}-1$ & $\mathrm{k}_{1}\left[\mathrm{CH}_{4}\right]\left[\mathrm{O}_{2}\right]$ & $\mathrm{k}_{1}=3,552 \times 10^{11} \times \mathrm{T}^{-1} \times \exp (-15700 / \mathrm{T})$ & Yan, et al. [11] \\
$\mathrm{R}-2$ & $\mathrm{k}_{2}\left[\mathrm{H}_{2}\right]^{1.5}\left[\mathrm{O}_{2}\right]$ & $\mathrm{k}_{2}=1,63142 \times 10^{11} \times \mathrm{T}^{-1.5} \times \exp (-3430 / \mathrm{T})$ & Yan, et al. [11] \\
$\mathrm{R}-3$ & $\mathrm{k}_{3}[\mathrm{CO}]\left[\mathrm{CO}_{2}\right]^{0.5}$ & $\mathrm{k}_{3}=3,16228 \times 10^{13} \times \exp (-16000 / \mathrm{T})$ & Bustamante, et al. [12] \\
$\mathrm{R}-4$ & $\mathrm{k}_{4}[\mathrm{CO}]^{0.5}\left[\mathrm{H}_{2} \mathrm{O}\right]$ & $\mathrm{k}_{4}=7,68 \times 10^{10} \times \exp (-36640 / \mathrm{T})$ & Bustamante, et al. [13] \\
R-5 & $\mathrm{k}_{5}\left[\mathrm{H}_{2}\right]^{0.5}\left[\mathrm{CO}_{2}\right]$ & $\mathrm{k}_{5}=6,4 \times 10^{9} \times \exp (-39260 / \mathrm{T})$ & Liu, et al. [14] \\
R-6 & $\mathrm{k}_{6}\left[\mathrm{O}_{2}\right]$ & $\mathrm{k}_{6}=\left(\frac{6}{d}\right) \times 250 \times \mathrm{T} \times \exp (-19004,1 / \mathrm{T})$ & Liu, et al. [14] \\
R-7 & $\mathrm{k}_{7}\left[\mathrm{CO}_{2}\right]$ & $\mathrm{k}_{7}=\left(\frac{6}{d}\right) \times 4346 \times \exp (-29839,5 / \mathrm{T})$ & \\
\hline \hline
\end{tabular}


Untuk mensimulasikan pembakaran yang terjadi di dalam reaktor diselesaikan persamaanpersamaan reaksi kimia. Reaksi kimia yang terjadi dibagi menjadi dua bagian, yang pertama adalah reaksi homogen dan heterogen. Daftar reaksi kimia tersebut dapat dilihat pada Tabel 3. Adapun kontanta kecepatan reaksi dari masing-masing persamaan reaksi kimia tersebut dapat dilihat pada Tabel 4. Untuk mensimulasikan reaksi homogen digunakan metode volume average, sedangkan reaksi heterogen menggunakan metode discrete.

\section{HASIL DAN PEMBAHASAN}

Gambar 3 (b) menunjukkan kesetimbangan tekanan dalam reaktor FBC dimana angka-angka adalah titik dilakukan sampling tekanan seperti pada gambar (a). Dari gambar ini dapat diketahui karakteristik hidrodinamika dari tiga variasi tidak banyak berbeda. Ketiganya menunjukkan posisi 6 di dasar standpipe mempunyai tekanan maksimal berkisar $111 \mathrm{kPa}$. Posisi 5 (saluran standpipe) mempunyai tekanan yang cukup rendah. Perbedaan tekanan antara posisi 6 dan 5 cukup besar kurang lebih $8 \mathrm{kPa}$ sehingga memungkinkan gas mengalir ke atas dari dasar standpipe.

Gambar 4 menunjukkan flow rate pasir. Secara umum tidak ada perbedaan signifikan antara ketiga variasi, berkisar 2030 2050 kg/s dan ada di dalam batas operasional yang diijinkan. Variasi 1 menunjukkan flow rate yang paling besar dibandingkan Variasi 2 dan 3 walaupun menggunakan EA paling sedikit. Hal ini diperkirakan disebabkan oleh temperatur rata-rata gas dalam riser Variasi 1 yang lebih tinggi sehingga kecepatan gaspun naik, yang pada akhirnya menyebabkan pasir mengalami fluidisasi lebih intensif.

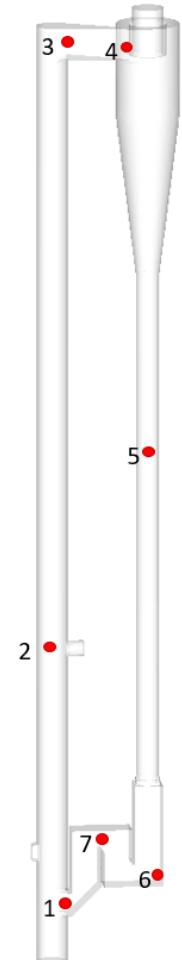

(a) Tempat Sampling

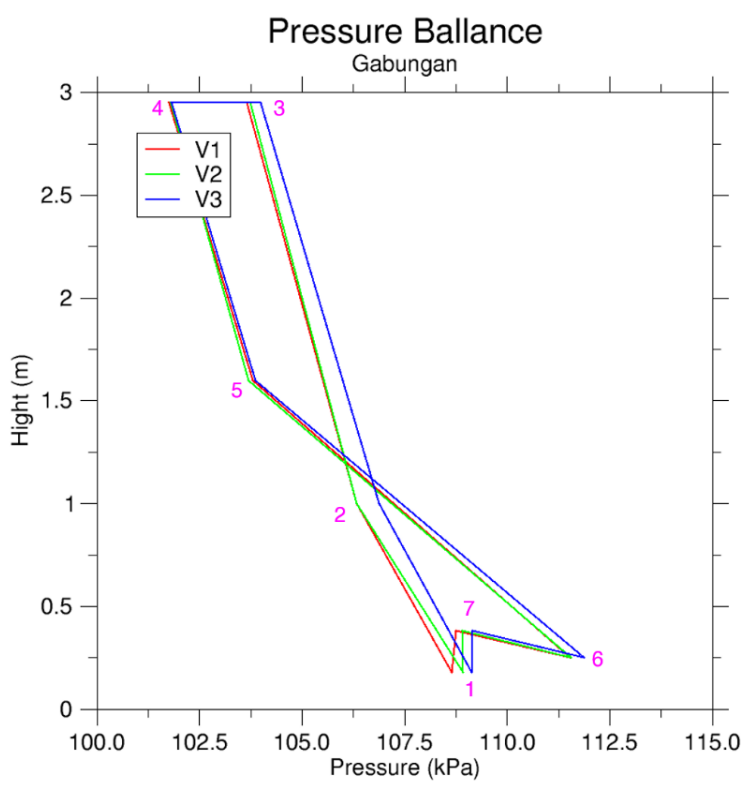

(b) Kesetimbangan Tekanan

Gambar 3 Distribusi Tekanan 


\section{Solid Circulation Rate}

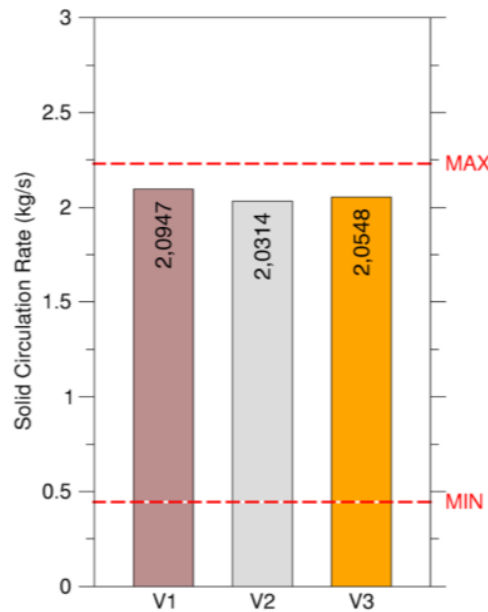

Gambar 4 Flow Rate Pasir

Gambar 5 menunjukkan komposisi gas buang di keluaran siklon. Hasil ini jika dibandingkan dengan perhitungan stoikiometris dengan asumsi pembakaran sempurna menunjukkan hasil yang hampir sama, sehingga pembakaran yang terjadi dapat dikatakan sudah sangat mendekati pembakaran sempurna. Tetapi jika grafik diperbesar di bagian bawah, seperti pada Gambar 6, dapat dilihat ada intermediate species dengan jumlah minor yang belum terbakar. Pada Variasi 1, walaupun AFR stoikiometrik, ternyata intermediate species berupa $\mathrm{CH}_{4}, \mathrm{CO}, \mathrm{H}_{2}$ masing-masing menunjukkan kurang lebih 1130 ppm, 2150 ppm, dan 4850 ppm. Pada Variasi 2 dan Variasi 3 yang menggunakan udara lebih maka intermediate species turun dengan drastis, bahkan untuk Variasi 3 menunjukkan angka di bawah $100 \mathrm{ppm}$. Hal ini menunjukkan udara lebih sangat berpengaruh terhadap kualitas flue gas.

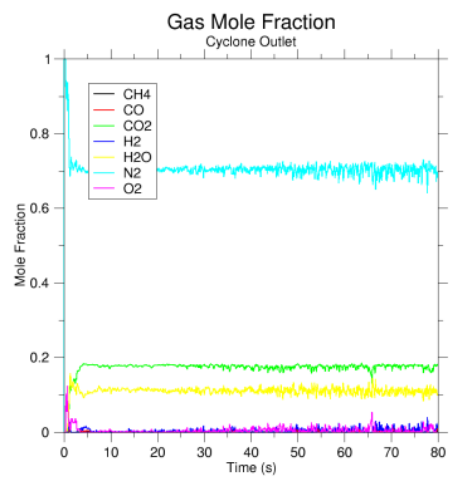

(a) Variasi 1

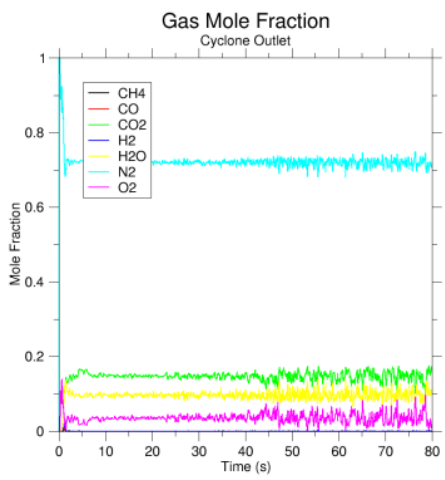

(b) Variasi 2

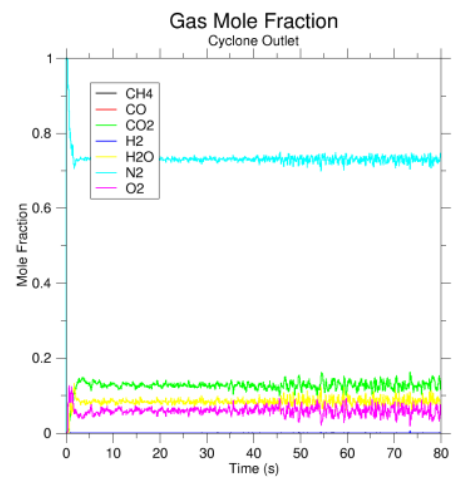

(c) Variasi 3)

Gambar 5 Spesies Mayor Pada Keluaran Siklon 


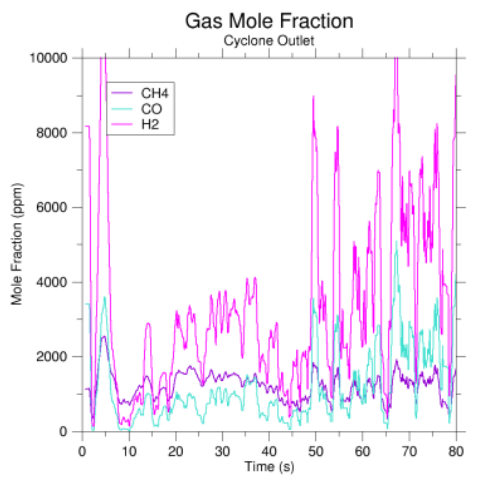

(a) Variasi 1

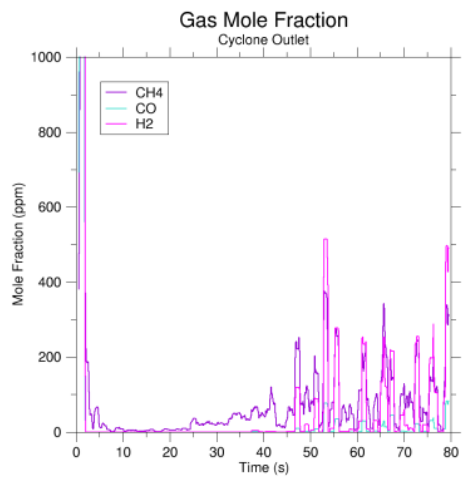

(b) Variasi 2

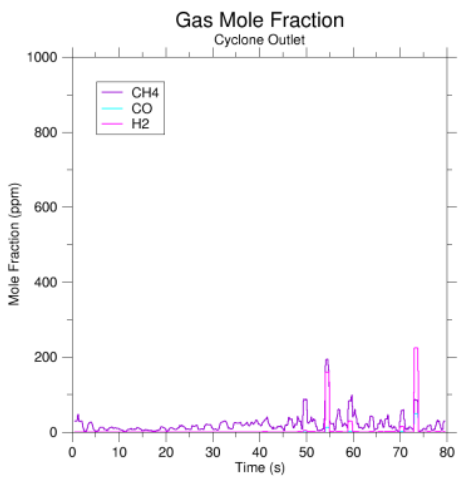

(c) Variasi 3)

Gambar 6 Spesies Minor Pada Keluaran Siklon

Kontur distribusi gas dalam reaktor dapat dilihat pada Gambar 7 yang menggambarkan fraksi massa masing-masing gas dalam reaktor. Dari gambar ini diketahui bahwa produk alami pembakaran $\mathrm{CO}_{2}$ dan $\mathrm{H}_{2} \mathrm{O}$ menunjukkan nilai tinggi pada daerah dekat dinding di atas inlet bahan bakar. Ini berarti bahwa batubara ketika masuk ke dalam reaktor tidak menyebar secara radial tetapi langsung terbawa aliran udara ke atas dengan menyusuri bagian tepi reaktor. Di bagian loopseal terlihat penumpukan $\mathrm{O}_{2}$ yang hal ini menunjukkan aliran udara dari riser menuju standpipe. Udara ini bertemu dengan partikel arang keluar dari siklon yang belum terbakar di standpipe.

Pada Variasi 1, gambar (a), banyak gas CO yang terbentuk pada bagian standpipe. Ini disebabkan banyak partikel arang yang tidak teroksidasi di riser, dan setelah masuk ke bagian standpipe tidak bertemu dengan cukup oksigen, sehingga partikel arang hanya terkonversi sampai gas $\mathrm{CO}$. Gas $\mathrm{CO}_{2}$ terbentuk secara masif di riser di bagian dekat dinding riser. Adapun $\mathrm{H}_{2} \mathrm{O}$ terbentuk hanya di bagian dekat dinding di atas inlet batubara. Pada Variasi 2, gambar (b), yaitu ketika udara lebih ditambahkan pada udara primer (udara sekunder nol) maka CO hampir tidak teramati di standpipe. Hal ini dikarenakan udara yang mengalir lewat loop-seal lebih banyak dan jumlahnya cukup untuk menyempurnakan proses pembakaran sehingga standpipe dipenuhi oleh gas $\mathrm{CO}_{2}$. Pada Variasi 3, gambar (c), fraksi massa $\mathrm{O}_{2}$ di bagian standpipe terlihat tinggi dan fraksi massa $\mathrm{CO}_{2}$ yang lebih rendah. Ini menunjukkan bahwa pada Variasi 3 ini lebih banyak batu bara yang terbakar di bagian riser dibanding pada Variasi 2. Hal tersebut dapat terjadi dikarenakan adanya suplai oksigen tambahan dari secondary air inlet saat partikel batubara sedang bergerak ke atas, yang menyebabkan batubara tersebut dapat teroksidasi dengan lebih baik di bagian riser.

Selanjutnya, Gambar 8 menunjukkan distribusi temperatur di dalam reaktor. Variasi 1 gambar (a) dan Variasi 2 gambar (b) menunjukkan pola yang mirip yaitu temperatur tinggi merata di dalam riser. Daerah dengan temperatur tinggi dimulai dari lubang inlet batubara sampai menjelang keluar menuju siklon. Pada Variasi 1 (a), di loop-seal ada hot-spot yang diperkirakan karena terjadinya reaksi pembakaran yang dapat dicek dari Gambar 7 (a) yang menunjukkan adanya konsentrasi $\mathrm{CO}_{2} \mathrm{dlm}$ loop-seal. Hal ini karena sebagian partikel arang yang tidak terbakar di riser, terperangkap dalam siklon, masuk ke standpipe tapi tidak bereaksi secara sempurna masih mempunyai temperatur cukup tinggi. Sehingga ketika mengalir ke loop-seal dapat bereaksi dengan udara yang bocor melalui loop-seal. Adapun untuk Variasi 3 gambar (c), daerah temperatur tinggi hanya sampai sekitar pertengahan riser. Akibat jumlah udara lebih yang banyak maka secara keseluruhan Variasi 3 menunjukkan temperatur yang lebih rendah. 


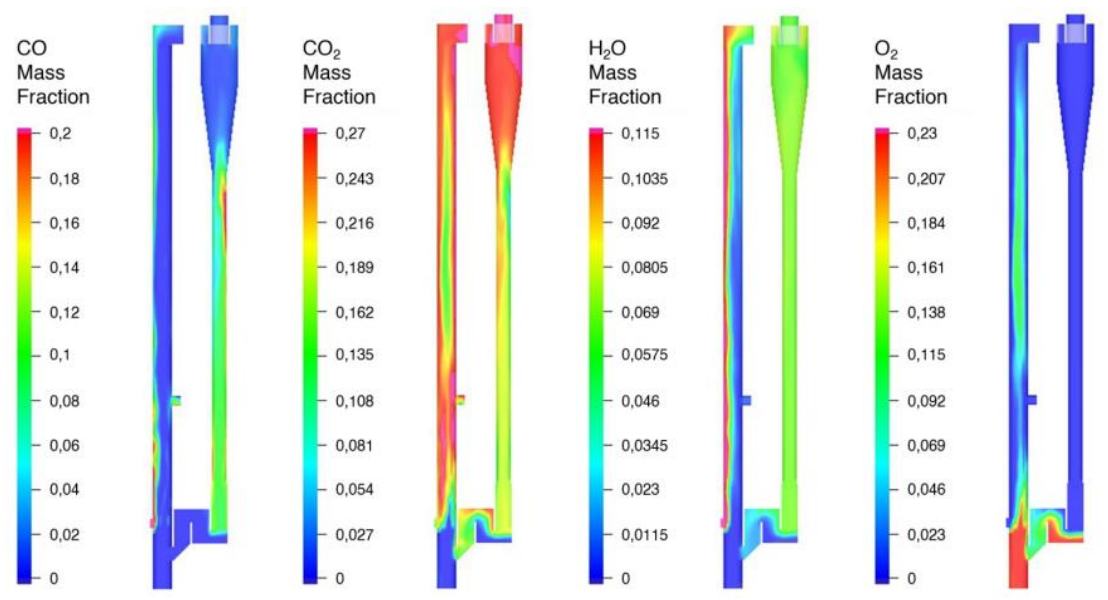

(a) Variasi 1

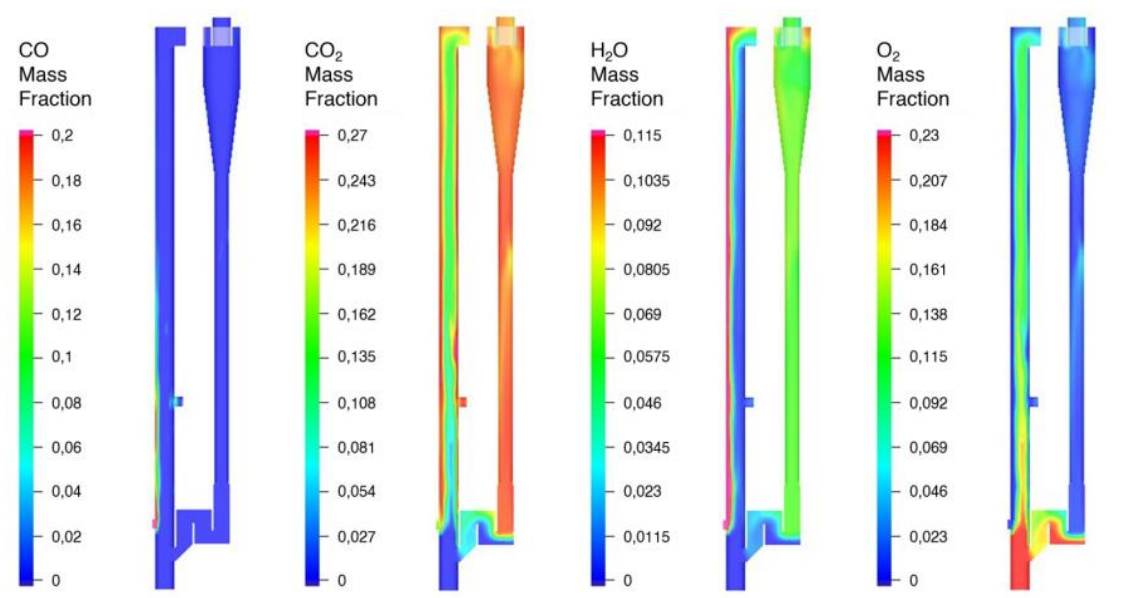

(b) Variasi 2

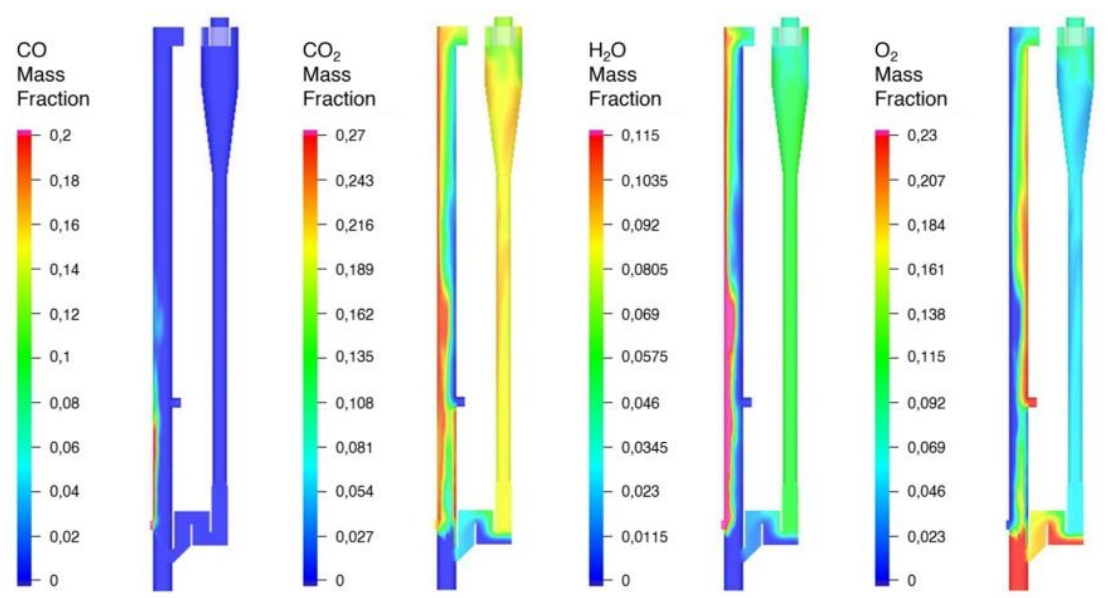

(c) Variasi 3

Gambar 7 Kontur Fraksi Massa Gas 


\section{Fluid \\ (K)

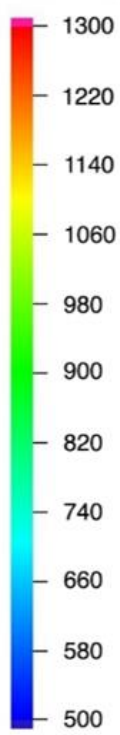

Temperature

Time (s)

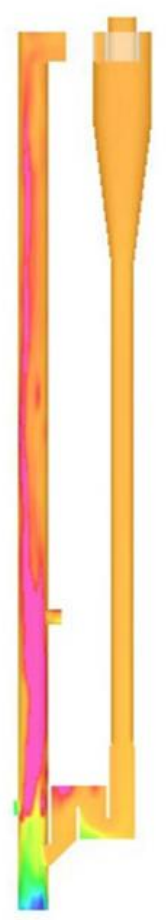

(a) Variasi 1

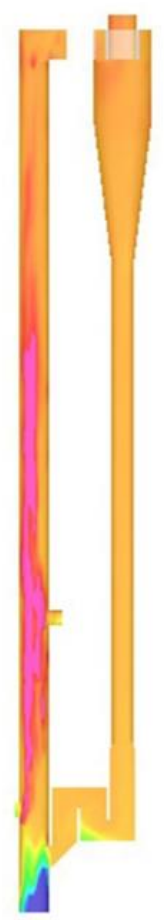

(b) Variasi 2

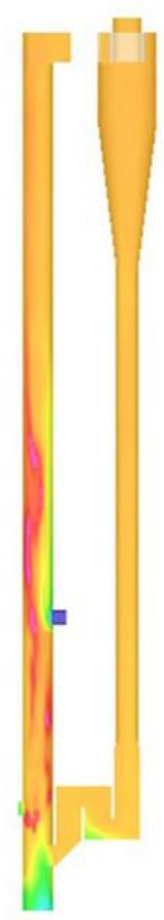

(c) Variasi 3

Gambar 8 Kontur Temperatur

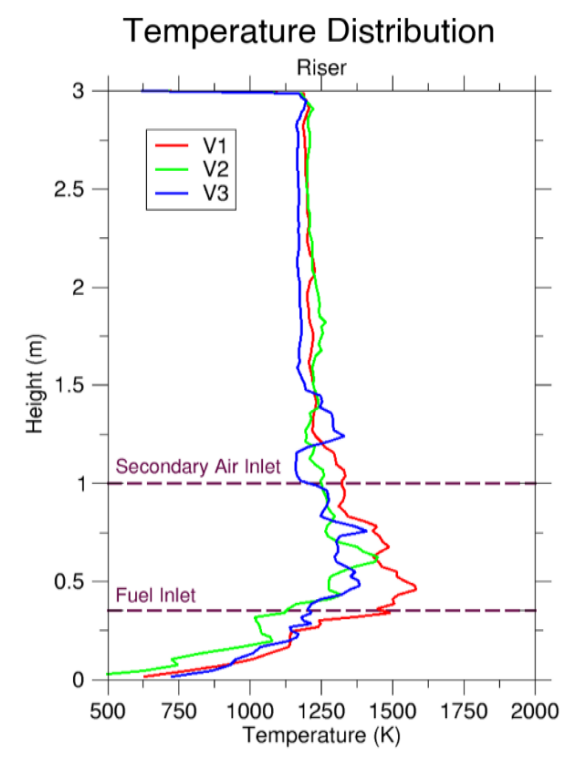

Gambar 9 Distribusi Temperatur Dalam Riser 
Gambar 9 menunjukkan distribusi temperatur di bagian tengah riser. Dari gambar ini dapat dilihat bahwa temperatur sepanjang riser untuk masing-masing variasi menunjukkan kecenderungan yang tidak jauh berbeda. Kenaikan temperatur dimulai dari daerah dekat distributor udara yang diakibatkan adanya resirkulasi pasir dari standpipe. Temperatur mencapai maksimum pada daerah di atas inlet bahan bakar, dimana Variasi 1, 2, dan 3 masing-masing kurang lebih sebesar $1600 \mathrm{~K}, 1450 \mathrm{~K}$, dan $1400 \mathrm{~K}$. Hal ini menunjukkan dengan semakin banyaknya jumlah udara maka menurunkan temperatur dalam riser. Di sisi lain, ketinggian dimana temperatur mencapai maksimum masing-masing kurang lebih adalah 50, 63, dan $75 \mathrm{~cm}$ untuk Variasi 1, 2, dan 3. Diperkirakan hal ini karena semakin besar jumlah udara (juga kecepatan udara), maka akan membuat batubara mengalami keterlambatan penyalaan.

Adapun zona reaksi yang terjadi Variasi 1 menunjukkan daerah yang lebih lebar (sampai sekitar 1,3 m) dibandingkan dengan Variasi 2 (sekitar 1,1 m) (zona reaksi adalah zona dimana terjadi reaksi pembakaran yang intensif dan ditunjukkan dengan temperatur yang lebih tinggi dibandingkan bagian atas riser). Hal ini menunjukkan Variasi 1 butuh zona reaksi lebih panjang dibandingkan Variasi 2. Ini karena jumlah udara Variasi 2 lebih banyak sehingga sebagian besar reaksi berlangsung lebih cepat. Adapun Variasi 3, karena adanya SA terjadi lonjakan temperatur di atas inlet SA yang menunjukkan reaksi pembakaran batubara yang lebih intensif sehingga dapat memperkecil terjadinya pembakaran di standpipe seperti dapat dilihat pada Gambar 7 (c).

\section{KESIMPULAN}

Berdasarkan hasil di atas, penambahan udara pada model CFBC yang digunakan pada penelitian ini berkontribusi sebagai berikut.

1. Tidak memberikan pengaruh besar terhadap karakteristik hidrodinamika berupa laju resirkulasi pasir dan kesetimbangan tekanan dalam reaktor.

2. Menyebabkan reaksi pembakaran di dapur akan menjadi lebih sempurna yang ditandai oleh semakin sedikitnya intermediate species pada flue gas. Hal tersebut dapat terjadi dikarenakan adanya udara berlebih akan menambahkan oksidator dalam reaksi sehingga meningkatkan peluang terjadinya pembakaran.

3. Menurunkan temperatur reaktor secara keseluruhan walaupun tidak signifikan.

4. Memperkecil terjadinya reaksi pembakaran di standpipe ketika digunakan udara lebih pada udara sekunder.

\section{UCAPAN TERIMA KASIH}

Penelitian ini dibiayai dengan skema Hibah Penelitian Departemen Teknik Mesin dan Industri Fakultas Teknik Universitas Gadjah Mada tahun 2020. Untuk itu penulis mengucapkan terima kasih yang sebesar-besarnya.

\section{DAFTAR PUSTAKA}

[1] Outlook Energi Indonesia 2020, Pusat Pengkajian Industri Proses dan Energi BPPT.

[2] Ryabov, G.A. 2016. "Development of the Circulating Fluidized Bed Combustion Technology: Studies of CFB Technology at VTI and the Justification for its Use in Russia". Power Technology and Engineering. Vol. 50, No. 4,

[3] Grace, J.R., et al. 1997. "Combustion Performance; Circulating Fluidized Beds". Chapman \& Hall, pp. 369-416. 
[4] Kang, Y., et al. 2000. "Effects of Secondary Air Injection on Gas-Solid Flow Behavior in Circulating Fluidized Beds". Chem Eng Comm. 177: 31-47.

[5] Kim, J.H. dan Shakourzadeh, K. 2000. "Analysis and Modeling of Solid Flow in a Closed Loop Circulating Fluidized Bed with Secondary Air Injection”. Powder Technol. 3: 179-185.

[6] Rao, K.V.N.S dan Reddy, G.V., 2008. "Effect of Secondary Air Injection on the Combustion Efficiency of Sawdust in a Fluidized Bed Combustor". Brazilian J. of Chem. Eng. 25:01, pp.129-141.

[7] Kobro, H. dan Brereton, C. 1986. "Control and Fuel Flexibility of Circulating Fluidised Bed”. Proceedings of the First International Conference on Circulating Fluidized Beds. Nova Scotia, Canada, pp 263-272

[8] Baskakov, A.P., et al. 1993. "Influence of Secondary Air on Convective Heat Transfer Between Walls of Riser and Circulating Fluidized Bed (CFB)". Proc. 4th Int'l Conf. on Circulating Fluidized Bed. Somerset, Pennsylvania, USA, pp. 380-383

[9] Lee, J.M., et al. 2013. "Evaluation of the Performance of a Commercial Circulating Fluidized Bed Boiler by Using IEA-CFBC Model, Effect of Primary to Secondary Air Ratio". Korean J. Chem. Eng. 30(5), pp. 1058-1066.

[10] Basu, P. 2015. "Circulating Fluidized Bed Boilers: Design, Operation and Maintenance”. Springer Int'l Pub. AG Switzerland.

[11] Yan, J., et al. 2020. "Validation and Application of CPFD Model in Simulating Gas-Solid Flow and Combustion of a Supercritical CFB Boiler with Improved Inlet Boundary Conditions". Fuel Processing Technology. 208, p.106512.

[12] Bustamante, F., et al. 2005. "Uncatalyzed and Wall-Catalyzed Forward Water-Gas Shift Reaction Kinetics”. AIChE Journal. 51 (5), pp. 1440-1454

[13] Bustamante, F., et al. 2004. "High-Temperature Kinetics of the Homogeneous Reverse Water-Gas Shift Reaction". AIChE Journal. 50 (5), pp. 1028-1041

[14] Liu, H., et al. 2019. "Vaporization Model for Arsenic during Single-Particle Coal Combustion: Model Development". Combustion and Flame. 205, pp.534-546. 